Discussion Paper No. 17-044

Energy Transition in Germany and Regional Spillovers: What Triggers the Diffusion of Renewable Energy in Firms?

Jens Horbach and Christian Rammer

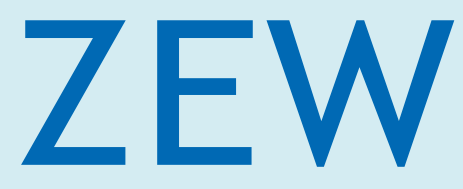

Zentrum für Europäische Wirtschaftsforschung $\mathrm{GmbH}$ Centre for European Economic Research 
Discussion Paper No. 17-044

\title{
Energy Transition in Germany and Regional Spillovers: What Triggers the Diffusion of Renewable Energy in Firms?
}

\author{
Jens Horbach and Christian Rammer
}

Download this ZEW Discussion Paper from our ftp server:

http://ftp.zew.de/pub/zew-docs/dp/dp17044.pdf

Die Discussion Papers dienen einer möglichst schnellen Verbreitung von neueren Forschungsarbeiten des ZEW. Die Beiträge liegen in alleiniger Verantwortung der Autoren und stellen nicht notwendigerweise die Meinung des ZEW dar.

Discussion Papers are intended to make results of ZEW research promptly available to other economists in order to encourage discussion and suggestions for revisions. The authors are solely responsible for the contents which do not necessarily represent the opinion of the ZEW. 


\title{
Energy Transition in Germany and Regional Spillovers: What Triggers the Diffusion of Renewable Energy in Firms?
}

\author{
Jens Horbach ${ }^{1}$, Christian Rammer ${ }^{2}$
}

October 2017

\begin{abstract}
The success of an energy turnaround towards renewables highly depends on the willingness and ability of firms to adopt energy technologies using renewable sources. Existing studies focused on the role of regulation and energy markets (e.g. the price for fossil energy) to explain the diffusion of green energy technologies. The present paper tries to give a more comprehensive view on the determinants of renewable energy innovations focusing on the crucial role of firms' regional environment (role of regional spillover effects, the greenness of a region and the regional endowment with green energy plants). We use a unique database combining the Community Innovation Survey 2014 for Germany and NUTS 3 data on renewable energy plants, the greenness of a region and other economic control variables. We find that geographical proximity to electricity production based on renewable energy sources and the orientation of a region towards 'green issues' (measured by the share of green party voters) are both major drivers for such innovations. Furthermore, our results show that in addition to regulation, government subsidies for eco-innovation, high energy costs and regional knowledge spillovers contribute to a rapid adoption of renewable energy. The reinforcing nature of this process leads to a diverging regional development of renewable energy innovations.
\end{abstract}

JEL-Classification: C25, O31, Q20, R11

Key Words: Eco-Innovation, Renewable Energy, Community Innovation Survey

\footnotetext{
${ }^{1}$ University of Applied Sciences Augsburg, Germany

${ }^{2}$ Centre for European Economic Research (ZEW), Mannheim, Germany
} 


\section{Introduction}

Shifting energy consumption from fossil sources to renewables is a key policy objective in many countries, including Germany. In 2016, Germany already attained a share of $29 \%$ of renewable energy sources in gross electricity generation while fossil energy sources still show a predominant share of $53.6 \%$ (hard coal $17.2 \%$, lignite $23.1 \%$, natural gas $12.4 \%$, oil $0.9 \%$ ) (BMWi 2017a). Following the goals of the German government, the share of renewables shall rise up to $45 \%$ in 2025 (BMWi 2017a). For 2050, a share of $80 \%$ is targeted. To reach these ambitious goals, innovations leading to a substitution of fossil energy sources by renewables are crucial.

At first glance, regulations such as the German renewable energy law seem to be one of the most important determinants to introduce renewable energy innovations (see Gawel et al. 2014, Frondel et al. 2010, Rammer et al. 2017) but the importance of this nationwide law cannot explain the significant regional differences in renewable energy innovation activities. In the innovation literature, regional spillovers (see Cantner et al. 2016) and tacit knowledge play a more and more important role whereas the growing literature on the determinants of eco-innovation widely neglects these effects. The present paper tries to assess the relevance of regional factors for innovation in renewable energy as an important subfield of ecoinnovation. We use a unique database combining three different sources. The main data source is the Community Innovation Survey (CIS) 2014 for Germany which contains detailed information on eco-innovation activities and their drivers, including innovations towards substituting fossil by renewable energy sources in a firm's process technologies. This firm-level database is matched with data on more than 1,400,000 renewable energy plants (solar, water, wind and biomass) and further regional indicators on the NUTS 3 level. These additional databases enlarge the already rich control variable set of the CIS by regional variables such as the greenness of a region and the existing capacities in the regional renewable energy production. Thus, we are able analysing if - besides "traditional" determinants such as environmental regulations or subsidies - the introduction of renewable energy innovations is also supported by regional spillover effects, the greenness of a region or the regional endowment with a green capital stock. Our econometric models assess the importance of these effects while controlling for the relevance of environmental policy measures, energy costs or the technological capabilities of a firm. 
The paper is organised as follows. Section 2 describes the theoretical framework of the relevance of regional spillover effects on renewable energy innovations besides further potential determinants. Furthermore, the section contains an overview of the existing empirical literature. In Section 3.1, the database, descriptive statistics and the econometric estimation strategy are discussed. Section 3.2 presents the estimation results. Section 4 concludes and develops policy recommendations.

\section{Determinants of Renewable Energy Innovations}

Renewable energy innovations can be defined as process or organisational innovations leading to a substitution of fossil energy sources by renewable sources within firms. In most cases, this substitution is cost-intensive so that government subsidies or rising costs of fossil energy sources may be trigger factors (e.g. Horbach et al. 2012, Grupp 1999) for renewable energy innovations. In addition, firms may be pushed to substitute fossil by renewable energy sources if regulation on emissions (e.g. $\mathrm{CO}_{2}$ ) becomes more stringent. While these factors usually affect all firms with a similar energy consumption pattern in the same way, substantial regional differences in renewable energy innovation can be observed in German regions (Länder). In general (Table 1), the West German Länder are more eco-innovative compared to the East, especially Rhineland-Palatinate, Baden-Wurttemberg and Bavaria. The two lastmentioned Länder also show a disproportionally high stock of solar and biomass plants per capita whereas the wind plants are more concentrated in the Northeast of Germany because of geographical reasons. Brandenburg shows high solar, biomass and wind values but not so many innovative firms, the technologies they apply seem to be predominantly developed elsewhere. North Rhine-Westphalia is highly innovative but seems not to be specialised in renewable energy innovations. 
Table 1: Regional distribution of innovation activities

\begin{tabular}{|l|c|c|c|c|}
\hline German Länder & $\begin{array}{c}\text { Share of re- } \\
\text { newable en- } \\
\text { ergy innova- } \\
\text { tors (\%) }\end{array}$ & $\begin{array}{c}\text { Share of in- } \\
\text { novative firms } \\
\text { (\%) }\end{array}$ & $\begin{array}{c}\text { Solar, bio- } \\
\text { mass } \\
\text { (kwp/capita) }\end{array}$ & $\begin{array}{c}\text { Wind } \\
\text { (kwp/capita) }\end{array}$ \\
\hline Baden-Wuerttemberg & 14.4 & 59.2 & 64.7 & 7.0 \\
Bavaria & 13.6 & 58.0 & 82.6 & 8.0 \\
Berlin & 4.4 & 55.3 & 3.1 & 0.1 \\
Brandenburg & 8.3 & 48.7 & 129.0 & 231.3 \\
Bremen & 13.4 & 60.2 & 6.9 & 22.5 \\
Hamburg & 8.1 & 56.8 & 4.7 & 2.7 \\
Hesse & 10.9 & 59.9 & 27.0 & 12.5 \\
Lower Saxony & 11.1 & 53.4 & 57.9 & 84.2 \\
Mecklenburg West-Pomerania & 9.8 & 48.7 & 38.0 & 64.5 \\
North Rhine-Westphalia & 8.7 & 59.3 & 27.9 & 20.5 \\
Rhineland-Palatinate & 14.3 & 62.3 & 46.5 & 49.2 \\
Saarland & 12.5 & 56.7 & 44.3 & 22.5 \\
Saxony & 7.7 & 55.2 & 18.3 & 11.6 \\
Saxony-Anhalt & 7.3 & 47.2 & 48.8 & 96.2 \\
Schleswig-Holstein & 7.5 & 51.9 & 70.1 & 147.8 \\
Thuringia & 10.8 & 56.1 & 56.4 & 50.3 \\
\hline Total & 10.5 & 56.7 & 47.4 & 32.5 \\
\hline
\end{tabular}

Source: Statistisches Bundesamt (2017), Community Innovation Survey 2014, own calculations.

The main aim of this paper is to explain these regional differences and to identify regional determinants of eco-innovations in the field of renewable energy. Whereas the literature on the determinants of eco-innovation is growing fast (see e.g. Barbieri et al. 2016 for a recent overview), the inclusion of regional aspects still remains rare (see Antonioli et al. 2016, Cantner et al. 2016, Horbach 2014 as exceptions). We argue that the regional factors play a prominent role in the diffusion of eco-innovations, particularly if a decentralised approach is followed. The decentralised approach rests on the conversion of energy from renewable sources into electricity or heat at the location of the energy users through small renewable energy facilities (photovoltaic cells, solar panels, biomass power plants, geothermal energy plants) or based on regional producer organisations (in the case of wind power) (Vona et al. 2012). In contrast, the centralised approach rests on firms from the energy sector who convert their production units from fossil to renewable energy sources and distribute electricity (or other forms of energy) based on renewables to their customers.

Germany largely followed the decentralised way. In this approach, adopting renewable energy technologies by energy consuming firms is a major driver for the energy transition. As with 
other innovations, uncertainty about the technical feasibility and the market prospects as well as high innovation costs can act as barriers.

On the background of regional economics (Krugman 1991, Asheim and Gertler 2005) the role of regional spillover effects, tacit knowledge and regional technology endowments has to be analysed. Furthermore, the green orientation of a region may lead to path dependencies. The so-called diamond model of Porter (Porter 2000, Eickelpasch et al. 2011) assumes that, firstly, the regional endowment with natural, human and capital resources, physical, administrative, informational, scientific and technological infrastructure, and the quality and the specialization of production factors determine the technological capabilities of a region. Furthermore, positive agglomeration effects result from the geographic proximity of (similar) firms, consumers and a fitting infrastructure (Eckey 2008). They can be divided in localization and urbanization advantages. Localization advantages describe the positive external effects resulting from the proximity of firms of the same industry whereas urbanization advantages result from the existence of a high number of firms of different industries and from typical advantages of highly concentrated urban areas (e.g. more leisure and cultural opportunities and a higher product diversity) (Eckey 2008). Audretsch (1998:1) states that "The spillover of knowledge from the firm or university creating that knowledge to a third-party firm is essential to innovative activity. Such knowledge spillovers tend to be spatially restricted". Asheim and Gertler (2005:291) even resume that "...the more knowledge-intensive the economic activity, the more geographically clustered it tends to be." The role of spatial proximity has been reinforced despite the increasing use of digital communication technologies because of the increasing importance of the so-called "...embedded tacit knowledge" (Asheim and Gertler 2005:292). Transferring this tacit knowledge usually requires face-to-face interaction. Especially the diffusion of organisational innovations such as the re-organisation of production units can strongly profit from mutual learning and the exchange of experience within regions since the codification of the critical knowledge e.g. through patenting and the trade of these innovations through embodied technology is restricted. Firms that have successfully implemented renewable energy systems will provide a 'role model' and encourage other firms to follow. Antonioli et al. (2016:5) stress that "The degree of closeness to other firms that adopt EIs [environmental innovations] and the presence of homogeneous institutional conditions in a given territory can influence the diffusion of EIs through knowledge transfer." 
Learning from other firms who have successfully adopted renewable energy technologies reduce information asymmetries over the technical and economic feasibility of new technologies. Such learning is strongly facilitated by geographic proximity to the peers (Audretsch 1998, Asheim and Gertler 2005) also because of the role of tacit knowledge that can only be transmitted by face-to-face contacts. Pioneers of renewable energy innovation in a region and specialised suppliers can demonstrate to other potential adopters how the innovation can work and speed up diffusion thus leading to localization advantages. Furthermore, the political and social environment in a region can push firms to adopt renewable energy innovation through social pressure. On the other side, firms may use the implementation of renewables as an instrument to improve their reputation. If regional actors highly value a transition towards a green economy, firms can profit from innovating in this area by gaining in reputation both with respect to attracting qualified labour and by a better marketing of their products.

All in all, the technological spillovers resulting from already existing renewable energy plants, specialised firms and workforce connected with the green orientation of the region (higher reputation of the firm) help compensating for higher costs of renewables in the short run. Based on these arguments, we derive the following hypotheses:

H1: The endowment of a region with renewable energy plants triggers the substitution of fossil energy.

H2: Localisation effects are important for the diffusion of renewable energy innovations.

H3: The orientation of a region towards 'green issues' promotes the substitution of fossil energy by renewables.

Regional factors are of course not the only determinants for renewable energy innovation. The literature on eco-innovation has been stressing the role of regulation and energy costs (e.g. Horbach et al. 2012, Demirel and Kesidou 2012). In addition, governments may provide subsidies for the adoption of renewable energy technologies, which naturally will increase their adoption. German has followed this approach with the Renewable Energy Sources Act (EEG). This law aims "...to increase the proportion of electricity generated from renewable energy sources as a percentage of gross electricity consumption to 1.40 to 45 percent by $2025,2.55$ to 60 percent by 2035 and 3. at least 80 percent by 2050" (BMWi 2017b:1). Fixed feed-in tariffs and purchase guarantees support the introduction of renewables energies by lowering the relative energy prices in favour of renewables so that their proportion of gross power con- 
sumption increased from 6\% in 2000 to 31.7\% in 2016 (BMWi 2017a). In order to test the relevance of regulation, subsidies and energy costs for renewable energy innovation, we formulate our hypothesis $\mathrm{H} 4$ :

H4: Government regulation, government subsidies and high energy costs increase the propensity of firms to adopt renewable energy technologies.

\section{Empirical studies on innovation in renewables}

The determinants of eco-innovation (see also Barbieri et al. 2016 or Horbach 2015 as overviews) in general have been extensively analysed. In the following, we summarise the results for the main recent studies concentrating on the determinants of the introduction and diffusion of renewable energy innovations as a special field of eco-innovation.

In a recent analysis, Schleich et al. (2017) explore the determinants of wind power technologies in twelve OECD countries using patent counts. The stock of wind capacity, a country's innovative capacity measured by the number of patents per capita and the legitimacy of wind technologies measured by the share of green party voters supports innovations in wind power technologies. Furthermore, a stable policy environment is important. Cantner et al. (2016) also use patent data to evaluate the influence of different policy instruments on technological change and efficiency gains in wind power and photovoltaics. The authors find significant differences between the driving forces of these renewable energy technologies. Whereas wind power is mostly driven by technology push instruments, demand pull seems to be more important for photovoltaics. Costantini et al. (2017) stress the point that a well-balanced policy mix of demand-pull and technology-push instruments is crucial for innovation in energy efficiency technologies.

Johnstone et al. (2010) analyse the effects of different policy instruments on the development of renewable energy technologies. Their patent analysis reveals a high importance of feed-intariffs for solar energy whereas more cost-competitive technologies such as wind power are not triggered by this policy instrument. Groba and Breitschopf (2013) confirm the crucial role of specific renewable energy policies to overcome market failures and barriers for the introduction of renewable energies.

Arvanitis et al. (2017) analyse effects of regulation measures, energy taxes and voluntary agreements and subsidies on the development of green energy product innovations for Aus- 
tria, Germany and Switzerland. If taxes and regulations do not support additional demand, their influence is negative with respect to energy product innovations whereas subsidies and voluntary agreements are positively correlated to energy product innovations.

Nesta et al. (2014) analyse the general determinants of renewable energy innovation. The authors consider policy-inducement mechanisms, the influence of the market structure, the demand and social cohesion and characteristics of countries' knowledge bases. Their patent analysis for different OECD countries from 1970 to 2005 shows a significantly negative influence of entry barriers and inequality on renewable energy innovation whereas product market liberalization triggers green patent generation, especially in combination with ambitious energy policies. Their patent analysis also accounts for the endogeneity of environmental policy. For 108 developing countries between 1980 and 2010, Pohl and Mulder (2013) detect a positive role of regulatory instruments, higher per capita income and schooling levels, and stable, democratic regimes on the diffusion of non-hydro related renewable energies. Conti et al. (2016) estimate the relevance of knowledge spillovers for renewable energy innovators from 1985 to 2010. The authors show that "EU RES inventors have increasingly built 'on the shoulders of the other EU giants'" (Conti et al. 2016:1).

Noailly and Smeets (2016:5) analyse the role of financial constraints for the realization of renewable energy innovations. They find that innovative newcomers in the field of renewable energy are especially concerned by financial constraints "...not solely because they are younger and less mature than other established firms, but mainly because they focus on new clean technologies that are still perceived as more risky by investors than the incumbent technologies based on fossil-fuel electricity generation." Furthermore, Foster et al. (2017) point to the problem that the cost of fossil fuel power generation will respond to the increase use of renewables thus leading to a delay of its diffusion. 


\section{Empirical Analysis of Renewable Energy Innovations in German Firms}

\subsection{Data, Estimation Strategy and Indicators}

Our study is based on a unique data set for Germany combining the Community Innovation Survey (CIS) of the reference year 2014, regional data at the NUTS 3 level and data on $1,486,036$ different renewable energy plants indicating the regionalised renewable energy capital stock. The CIS 2014 contained a separate module on eco-innovations. An ecoinnovation has been defined as follows: "An innovation with environmental benefits is a new or significantly improved product (good or service), process, organisational method or marketing method that creates environmental benefits compared to alternatives. The environmental benefits can be the primary objective of the innovation or a by-product of other objectives. The environmental benefits of an innovation can occur during the production of a good or service, or during its consumption or use by the end user of a product. The end user can be an individual, another enterprise, the Government, etc." (Eurostat 2015:12). The following contains a list of environmental benefits that an eco-innovation could have produced either within the firm or from the after-sale use of a product by the user for which surveyed firms should say whether this benefit has occurred or not. In addition, the survey asked firms whether any of these eco-innovations have been introduced in response to existing or expected environmental regulations, the availability of financial support by governments, demand from customers, or voluntary codes or industry agreements.

The German CIS 2014 covers 8,684 firms in mining and quarrying, manufacturing, energy and water supply, and a large number of service sectors. The response rate was $25 \%$ both for manufacturing and services which is in line with comparable non-mandatory surveys.

An analysis of the question on the determinants of all firms introducing renewable energy innovations shows that present regulations (27.5\%) and rising energy costs (33.3\%) are most important, the improvement of the reputation of the firm $(18.1 \%)$ is also a highly relevant factor (Table 2). 
Table 2: Determinants of the introduction of renewables

\begin{tabular}{|l|c|}
\hline Determinants & $\begin{array}{c}\text { Relevance of the determinants in \% of all } \\
\text { firms introducing renewables }\end{array}$ \\
\hline Present regulations & 27.5 \\
Environmental taxes & 9.8 \\
Expected future regulations or taxes & 15.6 \\
Subsidies & 8.1 \\
Present or expected demand & 8.8 \\
Reputation of the firm & 18.1 \\
Self-commitments or standards & 17.3 \\
Rising costs for energy or raw materials & 33.3 \\
\hline
\end{tabular}

Source: Community Innovation Survey 2014, own calculations.

Table 3: Relevant energy-related factors and barriers for the firm

\begin{tabular}{|l|c|c|}
\hline Factors & All firms & $\begin{array}{c}\text { Only renewable } \\
\text { energy innovators }\end{array}$ \\
\hline High or fluctuating energy prices & \multicolumn{2}{|c|}{ Highly relevant (\%) } \\
Bottlenecks in energy supply & 23.9 & 38.3 \\
Energy-related taxes & 20.7 & 7.6 \\
Energy related regulations (incl. tradable permits) & 9.9 & 32.9 \\
Self-commitments & 7.5 & 15.9 \\
Public subsidies & 12.0 & 12.6 \\
Demand for energy efficient products or renewa- & 7.5 & 19.5 \\
bles & Highly or very highly relevant (\%) \\
\hline Barriers & 30.8 & 40.9 \\
\hline Technology too expensive & 19.5 & 34.3 \\
Technology still in development & 15.5 & 23.5 \\
Lack of compatibility with already existing pro- & & 11.9 \\
cesses and products & 10.8 & 18.6 \\
Delay of investments because of anticipated de- & 30.3 & 44.2 \\
creasing prices & 21.8 & 33.9 \\
Amortisation time too long & 15.8 & 19.4 \\
High economic risk & 8.8 & 14.9 \\
Lack of financial sources & 14.4 & 25.2 \\
Lack of qualified personnel & 22.8 & 35.1 \\
Complicated bureaucratic processes & 23.0 & 20.7 \\
Lack of political framework conditions & & \\
Leeway for actions is restricted (e. g. a building is & & \\
only rented) & & \\
\hline Souc: Comnnity & & \\
\hline
\end{tabular}

Source: Community Innovation Survey 2014, additional survey on energy technologies.

An additional survey of a subsample of the firms that participated in the CIS 2014 (see Rammer et al. 2017 for details) shows further energy-related factors and barriers of the introduc- 
tion of renewable energy innovations (Table 3). The results show that high or fluctuating energy prices, taxes, regulations and public subsidies are especially relevant for renewable energy innovators. On the other side, complicated bureaucratic processes and a lack of political framework conditions are barriers for renewable energy innovations. Furthermore, the economic risk introducing renewables seems to be higher compared to all firms in the sample.

\section{Estimation strategy}

In a first step, we estimate the probability to introduce innovations that help substituting fossils by renewables compared to all other firms in the sample. In a second step, we restrict our sample to eco-innovators, only. This analysis aims at analysing the specificities of renewable energy innovations compared to other eco-innovation fields especially the role of regulation and cost-savings as motivation. Unfortunately, the data basis does not allow analysing the role of regulation for the whole sample because the regulation variable is only available for ecoinnovators.

In all models, regional variables at the NUTS 3 level are matched to the firm-level data of the CIS leading to possible intra-cluster correlation so that the standard errors using normal probit models would be too low. We use multilevel mixed effects probit models to account for this problem and probit models with clustered standard errors as a robustness check. As cluster size in our sample varies significantly from 1 to 725 firms in a cluster multilevel mixed effects models are the more adequate choice.

Our two-level mixed-effects probit regression contains both random and fixed effects. The model reads as follows (STATACorp 2015): We have to consider a two-level model for a series of 396 clusters (396 regional German NUTS 3 units)

$\operatorname{Pr}\left(\mathrm{y}_{\mathrm{ij}}=1\right)=\mathrm{H}\left(\mathbf{x}_{\mathrm{ij}} \boldsymbol{\beta}+\mathbf{u}_{\mathrm{j}}\right)$

for $\mathrm{j}=1 ; \ldots ; 396$ clusters, with cluster $\mathrm{j}$ consisting of $\mathrm{i}=1 ; \ldots ; \mathrm{n}_{\mathrm{j}}$ observations. The responses $\mathrm{y}_{\mathrm{ij}}$ are the binary-valued renewable $\mathrm{ij}_{\mathrm{ij}}$. The vector $\mathbf{x}_{\mathrm{ij}}$ are the covariates for the fixed effects, whereas the vector $\mathbf{u}_{\mathrm{j}}$ analogously represents the random effects. The basis of this model is the variance components model (stated as latent linear response): $y_{i j}^{*}=\mathbf{x}_{\mathrm{ij}} \beta+\mathrm{u}_{\mathrm{j}}+\varepsilon_{\mathrm{ij}}$, where the errors $\varepsilon_{\mathrm{ij}}$ are distributed as normal and are independent of the random effects $\mathrm{u}_{\mathrm{j}}$. The log likelihood function is approximated by Gauss-Hermite quadrature (STATACorp 2015, Cameron and Trivedi 2009). 


\section{Measurement of variables}

A description of all model variables along with descriptive statistics is provided in the Appendix. Our dependent variable Renewable gets the value one if the firm has realised an innovation that led to a substitution of fossil energy sources by renewables.

The determinants of innovations in renewable energy considered in this paper are summarised in Table 4. Regional spillover effects are represented by six variables. Popdens describes the population density of a region and accounts for agglomeration effects. The variable Sharegreen describes the voting share of the green party in 2013 and indicates the greenness of a region thus also describing the social acceptance of green issues by relevant stakeholders (Schleich et al. 2017). Solbiocapita captures the installed capacity of solar and biomass energy plants in kwp per capita. Watercapita and Windcapita are the respective variables for water and wind energy plants. These variables capture the already available regional capital stock of renewable energy plants. Secshare captures the sector share of the sector to which the firm belongs in the respective NUTS 3 unit describing localization effects.

Table 4: Determinants of the introduction of renewable energies at the firm level

\begin{tabular}{|l|l|}
\hline Determinants & Indicators \\
\hline Regional spillover effects & $\begin{array}{l}\text { Popdens, Secshare, Sharegreen, Solbiocapita, } \\
\text { Watercapita, Windcapita }\end{array}$ \\
\hline Technological capabilities & $\begin{array}{l}\text { Orgcoop, Orgproc, Orgwork, Coopown, Coopcli- } \\
\text { ent, Coopsuppcomp, Coopresearch, Internrd, } \\
\text { Externrd, Highqual }\end{array}$ \\
\hline Political measures and further determinants & $\begin{array}{l}\text { Subsidies } \\
\text { only eco-innovators: Regulation, Taxes, Fu- } \\
\text { turelaw, Ecosubsidies, Demand, Reputation, } \\
\text { Selfcommitment }\end{array}$ \\
\hline Costs & Energcost (only eco-innovators), Profit \\
\hline Competitive environment & Competition, International, Number competitors \\
\hline Appropriation of knowledge & Patents, Designs, Trademarks, Copyrights \\
\hline Further control variables & Agefirm, Family, Size \\
\hline
\end{tabular}

The technological capabilities are captured by the following variables: Internrd gets the value 1 if the firm realises internal R\&D activities, Externrd describes external R\&D activities. Highqual denotes the share of employees with a university degree. The different cooperation partners are captured by the following variables: Coopown (firms within the own firm group), Coopclient (cooperation with private and public customers), Coopsuppcomp (suppliers and 
competitors), Coopresearch (consulters, universities, public and private research institutes). The variables Orgproc (new methods organising business processes), Orgwork (new methods organising labour, e g. teamwork or job rotation), Orgcoop (change of the organisation of external relationships to other firms, e. g. integration of suppliers) describe organisational innovations. Subsidies captures whether a firm has received public subsidies for innovation.

The variables on the policy determinants of eco-innovation are only available for firms with eco-innovations. They get the value 1 if a determinant is rated as highly or medium important, and 0 otherwise and include Regulation (present regulations), Taxes (environmental taxes), Futurelaw (future regulations), Ecosubsidies (public subsidies of eco-innovations). In addition, Demand (present or anticipated demand), Reputation (improvement of the reputation of the firm) and Selfcommitment cover further factors that may drive innovations in renewable energy. Cost-side determinants include Energcost (rising costs of energy or other raw materials, only available for eco-innovators) and Profit which represents the financial situation of the firm (measured by the profit margin).

The competitive environment of a firm is represented by three indicators. International equals one if a firm is active in markets outside Germany. Competition and Number competitors capture the competition pressure of the firm. Potential knowledge appropriation problems are captured by the following variables: Patents (application of a patent), Designs (use of utility models and registered designs), Trademarks (application of trademarks) and enforcement of Copyrights. Furthermore, sector dummies are included. Three variables capture structural characteristics of the firm. Size is measured by the number of employees. The variable Agefirm gives the age of the firm in years. Family gets the value one if the firm is dominated by one family (at least more than a $50 \%$ share).

\subsection{Estimation results}

Firms substituting fossils by renewables compared to all firms

The results of both the probit model with clustered standard errors and the two-level mixed effects models (see Table 5) show significant effects of regional variables. A green orientation of a region (Sharegreen) seems supporting the willingness of firms to implement renewable energy technologies supporting our hypothesis H3 and the recent analysis of Schleich et al. (2017). The share of green party voters may be interpreted as "...social acceptance of renew- 
able energy technologies" (Schleich et al. 2017:688). Furthermore, a high share of solar and biomass (Solbiocapita) in the region is connected with a higher substitution of fossil energy within firms pointing to considerable regional spillover effects (Conti et al. 2017) and supporting H1. The firms seem to use existing regional experiences by learning from other firms (see Section 2) and capacities in renewables for their own substitution process of fossil fuels. This result does not hold for water and wind power plants as these power plants are highly dependent on geographical conditions. Agglomeration in the sense of urbanization effects do not seem to be a pre-condition for renewable energy innovations within firms, the indicator population density (Popdens) is even significantly negative whereas localization effects measured by a high presence of similar firms in the region are significantly relevant for renewables (Secshare) supporting H2. We also estimated models where we controlled for the Energy intensity of the firm but, interestingly, the respective variable always remained insignificant. This may be due to the fact that energy intensive firms especially those having own power plants would have to realise high investment costs to change their energy mix. As the variable Energy intensity causes a drastic reduction of observations, we renounced including this insignificant variable.

The substitution process from fossils to renewables is highly driven by organisational innovations within a firm. The introduction of new methods organising business processes (Orgproc), new forms of labour organisation (Orgwork), new cooperation arrangements, the change of customer relationships and a better integration of suppliers (Orgcoop) help to realise renewable energy innovations. Concerning cooperation partners, energy innovative firms mostly rely on firms from the same group of companies (Coopown) as cooperation partners. Bigger and family owned firms are more likely to introduce renewable energies (size, Family). The positive size-effect may be explained by the higher available resources to bear the costs of the introduction of renewable energy innovations. Family dominated firms might have a higher preference to improve their reputation and social responsibility. The realization of renewable energy innovations is furthermore supported by subsidies, especially from ministries such as the environmental ministry (Subsidies). 
Table 5: Determinants of the substitution of fossil energy sources by renewables all firms

\begin{tabular}{|c|c|c|}
\hline \multicolumn{3}{|c|}{ Dependent variable: Renewable: substitution of fossil energy sources by renewables } \\
\hline Regressors & $\begin{array}{l}\text { Two-level mixed-effects probit } \\
\text { regression }\end{array}$ & $\begin{array}{c}\text { Probit model with clustered } \\
\text { standard errors }\end{array}$ \\
\hline \multicolumn{3}{|l|}{ Regional variables } \\
\hline Popdens & $-0.02(-4.39)^{* * *}$ & $-0.02(-4.91)^{* * *}$ \\
\hline Secshare & $0.09(2.01)^{* *}$ & $0.09(2.15)^{* *}$ \\
\hline Sharegreen & $0.51(3.36)^{* * *}$ & $0.49(3.49)^{* * *}$ \\
\hline Solbiocapita & $0.17(2.04)^{* *}$ & $0.15(1.94)^{* *}$ \\
\hline Watercapita & $0.97(1.31)$ & $1.00(1.51)$ \\
\hline Windcapita & $-0.02(-0.38)$ & $-0.02(-0.32)$ \\
\hline \multicolumn{3}{|c|}{ Technological capabilities } \\
\hline Externrd & $0.01(0.55)$ & $0.01(0.57)$ \\
\hline Internrd & $0.04(3.94)^{* * *}$ & $0.04(3.93)^{* * *}$ \\
\hline Orgcoop & $0.04(4.05)^{* * *}$ & $0.04(4.20)^{* * *}$ \\
\hline Orgproc & $0.05(5.10)^{* * *}$ & $0.05(5.10)^{* * *}$ \\
\hline Orgwork & $0.03(3.05)^{* * *}$ & $0.03(3.00)^{* * *}$ \\
\hline Coopown & $0.06(3.78)^{* * *}$ & $0.07(3.76)^{* * *}$ \\
\hline Coopclient & $-0.03(-1.78)^{*}$ & $-0.03(-1.84)^{*}$ \\
\hline Coopsuppcomp & $0.04(2.45)^{* * *}$ & $0.04(2.48)^{* * *}$ \\
\hline Coopresearch & $-0.01(-0.52)$ & $-0.01(-0.59)$ \\
\hline Highqual & $-0.02(-0.95)$ & $-0.02(-0.99)$ \\
\hline \multicolumn{3}{|l|}{ Further variables } \\
\hline Agefirm & $0.22(2.44)^{* * *}$ & $0.22(2.52)^{* * *}$ \\
\hline Competition & $0.03(3.19)^{* * *}$ & $0.03(3.23)^{* * *}$ \\
\hline Family & $0.03(3.87)^{* * *}$ & $0.03(3.87)^{* * *}$ \\
\hline International & $-0.01(-0.60)$ & $-0.00(-0.60)$ \\
\hline Number Competitors & $0.02(2.40)^{* *}$ & $0.02(2.43)^{* * *}$ \\
\hline Profit & $0.03(4.37)^{* * *}$ & $0.03(4.38)^{* * *}$ \\
\hline Size & $0.004(2.17)^{* *}$ & $0.004(2.16)^{* *}$ \\
\hline \multirow[t]{4}{*}{ Subsidies } & $0.07(2.09)^{* *}$ & $0.08(2.06)^{* *}$ \\
\hline & No. obs.: 7,202 & No. obs.: 7,202 \\
\hline & No. groups: 396 & Wald $\chi 2(47)=994^{* * *}$ \\
\hline & Wald $\chi^{2}(47)=689^{* * *}$ & Pseudo $\mathrm{R}^{2}=0.12$ \\
\hline
\end{tabular}

\section{Specificities of renewables compared to other eco-innovations}

In a second step, we restrict our analysis to eco-innovators so that the variables on different eco-innovation determinants can also be exploited. This analysis helps to detect specificities of renewable energy innovations compared to other eco-innovation fields. In this model, we 
also controlled for the appropriation strategies of firms because they might influence the results of the variables describing the determinants. The results show (Table 6) that present regulations and taxes (Regulation, Taxes) are less important for renewables compared to other eco-innovations whereas the firms perceive a positive influence of expected future regulations (Futurelaw) on their renewable energy innovations. The improvement of the Reputation of the firm is significantly more important for renewable energy innovations compared to other eco-innovations confirming our argumentation in Section 2. Rising energy costs (Energcost) seem to be a main motive to introduce renewables supporting H4. Firms in regions with an already high amount of solar energy and water-based plants (Solbiocapita, Watercapita) are more likely to substitute fossil energy by renewables also supporting H1. The green orientation (Sharegreen) of a region is more important for renewable energy innovations compared to other eco-innovation fields (H3). The result that Family owned firms are more likely to realise renewable energy innovations is also confirmed when only eco-innovators are considered. A higher competition measured by the Number of Competitors also triggers renewable energy innovations. Bigger (Size) firms are also more likely to introduce renewables. These firms seem to have fewer constraints to finance the switch from fossil energy to renewables. Furthermore, this switch is only successful when the firms are capable and active in the introduction of new methods of business processes. The significant influence of the variable Orgproc indicates that a re-organisation of the whole production process is especially important for renewables compared to other eco-innovations. This argumentation is confirmed by the positively significant variable Coopown denoting the relevance of cooperation partners from the own firm group. 
Table 6: Determinants of the substitution of fossil energy sources by renewables - ecoinnovators only

\begin{tabular}{|c|c|c|}
\hline \multicolumn{3}{|c|}{ Dependent variable: Renewable: substitution of fossil energy sources by renewables } \\
\hline Regressors & $\begin{array}{l}\text { Two-level mixed-effects probit } \\
\text { regression }\end{array}$ & $\begin{array}{c}\text { Probit model with clustered } \\
\text { standard errors }\end{array}$ \\
\hline $\begin{array}{l}\text { Regional variables } \\
\text { Popdens } \\
\text { Secshare } \\
\text { Sharegreen } \\
\text { Solbiocapita } \\
\text { Watercapita } \\
\text { Windcapita }\end{array}$ & $\begin{array}{c}-0.04(-4.82)^{* * *} \\
0.14(1.89)^{*} \\
0.71(3.17)^{* * *} \\
0.19(1.91)^{*} \\
1.94(1.83)^{*} \\
0.04(0.47)\end{array}$ & $\begin{array}{c}-0.04(-4.97)^{* * *} \\
0.15(1.96)^{* *} \\
0.74(3.21)^{* * *} \\
0.20(1.89)^{*} \\
2.10(1.92)^{* *} \\
0.04(0.48)\end{array}$ \\
\hline $\begin{array}{l}\text { Technological capabi } \\
\text { Externrd } \\
\text { Internrd } \\
\text { Orgcoop } \\
\text { Orgproc } \\
\text { Orgwork } \\
\text { Coopown } \\
\text { Coopclient } \\
\text { Coopsuppcomp } \\
\text { Coopresearch } \\
\text { Highqual }\end{array}$ & $\begin{array}{c}-0.02(-1.09) \\
0.01(0.56) \\
0.03(1.72)^{*} \\
0.03(2.37)^{* *} \\
0.01(1.02) \\
0.07(2.72)^{* * *} \\
-0.06(-2.18)^{* *} \\
0.03(1.23) \\
-0.02(-0.93) \\
0.02(0.62)\end{array}$ & $\begin{array}{c}-0.02(-1.09) \\
0.01(0.56) \\
0.03(1.76)^{*} \\
0.04(2.36)^{* *} \\
0.01(1.00) \\
0.08(2.70)^{* * *} \\
-0.05(-2.19)^{* *} \\
0.03(1.24) \\
-0.02(-0.97) \\
0.02(0.62)\end{array}$ \\
\hline $\begin{array}{l}\text { Determinants } \\
\text { Regulation } \\
\text { Taxes } \\
\text { Futurelaw } \\
\text { Ecosubsidies } \\
\text { Demand } \\
\text { Reputation } \\
\text { Selfcommitment } \\
\text { Energcost }\end{array}$ & $\begin{array}{c}-0.04(-2.52)^{* * *} \\
-0.03(-1.64)^{*} \\
0.07(4.28)^{* * *} \\
0.03(1.79)^{*} \\
0.02(1.30)^{*} \\
0.04(2.40)^{* *} \\
0.03(1.84)^{*} \\
0.06(4.93)^{* * *}\end{array}$ & $\begin{array}{c}-0.04(-2.53)^{* * *} \\
-0.03(-1.65)^{*} \\
0.08(4.27)^{* * *} \\
0.03(1.78)^{*} \\
0.03(1.31) \\
0.05(2.42)^{* *} \\
0.03(1.85)^{*} \\
0.07(4.90)^{* * *}\end{array}$ \\
\hline $\begin{array}{l}\text { Appropriation } \\
\text { Patents } \\
\text { Designs } \\
\text { Trademarks } \\
\text { Copyrights }\end{array}$ & $\begin{array}{c}0.01(0.74) \\
0.04(2.04)^{* *} \\
0.00(0.23) \\
0.04(1.69)^{*}\end{array}$ & $\begin{array}{c}0.01(0.74) \\
0.05(1.97)^{* *} \\
-0.01(-0.27) \\
0.04(1.73)^{*}\end{array}$ \\
\hline $\begin{array}{l}\text { Control variables } \\
\text { Agefirm } \\
\text { Competition } \\
\text { Family } \\
\text { International } \\
\text { Number Competitors } \\
\text { Profit } \\
\text { Size }\end{array}$ & $\begin{array}{c}0.09(0.68) \\
0.02(1.90)^{*} \\
0.04(3.57)^{* * *} \\
-0.02(-1.79)^{*} \\
0.04(3.16)^{* * *} \\
0.04(4.02)^{* * *} \\
0.03(4.64)^{* * *}\end{array}$ & $\begin{array}{l}0.10(0.70)^{* *} \\
0.03(1.93)^{* *} \\
0.04(3.53)^{* * *} \\
-0.03(-1.80)^{*} \\
0.04(3.16)^{* * *} \\
0.05(4.05)^{* * *} \\
0.03(4.57)^{* * *}\end{array}$ \\
\hline & $\begin{array}{c}\text { No. obs.: } 4,427 \text {, No. groups }=390 \\
\text { Wald } \chi 2(57)=825^{* * *}\end{array}$ & $\begin{array}{l}\text { No. obs.: } 4,427, \text { Wald } \chi 2(57) \\
=1001^{* * *}, \text { Pseudo } \mathrm{R}^{2}=0.12\end{array}$ \\
\hline
\end{tabular}

Marginal effects, z-statistics shown in parentheses. ${ }^{*},{ }^{* *}$ and ${ }^{* * *}$ denote significance at the $10 \%, 5 \%$ and $1 \%$ level, respectively. Sector dummies and constants are included but not reported.

Source: Community Innovation Survey 2014, own estimations. 


\section{Conclusions and Policy Implications}

The transition from fossil to renewable energy in Germany aims at substituting the majority of fossil energy sources by renewables for the production of electricity. Up to now, hard coal and lignite still show a high share of about $40 \%$. To reach the ambitious goal of $80 \%$ of renewables in 2050, innovation activities leading to an increase of the use of renewables are crucial. Following the respective literature, regulation activities and an adequate policy mix of technology push and demand pull measures are mainly responsible and necessary for the diffusion of renewable energy. Despite the fact that most of the relevant political measures in Germany such as the renewable energy law are nation-wide, the distribution of the renewable energy innovation activities is considerably different between regions. The present paper tries to assess the reasons for these regional disparities in the diffusion of renewable energy innovations. Our econometric analysis is based on a unique combination of three databases: The main source is firm level data from the Community Innovation Survey (CIS) 2014 for Germany. This database has been merged with regional data on the NUTS 3 level and data on nearly 1.5 million renewable energy plants (solar, biomass, gas, water and wind).

The results of our econometric analyses show that regional variables are highly relevant for the renewable energy innovation dynamics. A green orientation of a region measured by the share of green voters seems supporting the willingness of firms to implement renewable energy technologies. Furthermore, a high share of solar and biomass in the region is connected with a higher substitution of fossil energy within firms pointing to considerable regional spillover effects. The firms seem to use existing regional experiences ("tacit knowledge") and capacities in renewables for their own substitution process of fossil fuels. The substitution process from fossils to renewables is highly driven by organisational innovations within a firm. The introduction of new methods organising business processes, new forms of labour organisation, new cooperation arrangements, the change of customer relationships and a better integration of suppliers help to realise renewable energy innovations.

Restricting our analysis to eco-innovators only helps to detect specificities of renewable energy innovations compared to other eco-innovation fields. The results show that present regulations and taxes are less important for renewables compared to other eco-innovations whereas the firms perceive a positive influence of expected future regulations on their renewable energy innovations. The improvement of the reputation of the firm is more important for renewable energy innovations compared to other eco-innovations. Rising energy costs seem to be a 
main motive to introduce renewables. Firms in regions with an already high amount of solar and biomass energy plants are more likely to substitute fossil energy by renewables.

All in all, the analysis shows that a green orientation and the existing capacities of renewables in a region matter and encourage more renewable energy innovations thus leading to path dependencies. Therefore, not only "hard" regulation measures such as the renewable energy law are relevant for the realization of renewable energy innovations but also soft instruments that strengthen the green orientation of a region supporting substitution processes from fossil to renewable energy. Measures that encourage the social and environmental responsibility of firm leaders and the environmental consciousness of the population of a region seem to be important for the diffusion of renewable energy innovations. 


\section{References}

Antonioli, D., Borghesi, S., Mazzanti, M. (2016): Are regional systems greening the economy? Local spillovers, green innovations and firms' economic performances. Economics of Innovation and New Technologies 25 (7): 692-713.

Arvanitis, S., Peneder, M., Rammer, C., Stucki, T., Wörter, M. (2017): Development and Utilization of Energy-related Technologies, Economic Performance and the Role of Policy Instruments, Journal of Cleaner Production 159: 47-61.

Asheim, B., Gertler, M. S. (2005): The Geography of Innovation: Regional Innovation Systems. In: Fagerberg, J., Mowery, D. C., Nelson, R. R. (eds.) (2005): The Oxford Handbook of Innovation, Oxford University Press, New York: 291-317.

Audretsch, D. (1998): Agglomeration and the Location of Innovative Activity. Oxford Review of Economic Policy, 14 (2): 18-29.

Barbieri, N., Ghisetti, C., Gilli, M., Nicolli, F. (2016): A Survey of the Literature on Environmental Innovation based on Main Path Analysis. Journal of Economic Surveys 30: 596-623. doi:10.1111/joes.12149.

BMWi (Federal Ministry for Economic Affairs and Energy) (2017a): For a future of green energy, Berlin, https://www.bmwi.de/Redaktion/EN/Dossier/renewable-energy.html

BMWi (Federal Ministry for Economic Affairs and Energy) (2017b): Renewable Energy Sources Act (EEG 2017), Berlin, https://www.clearingstelle-eeg.de/files/node/8/EEG 2017 Englische Version.pdf

Cameron, A. C., Trivedi, P. K. (2009): Microeconometrics using Stata. Stata Press, Lakeway Drive.

Cantner, U., Graf, H., Herrmann, J., Kalthaus, M. (2016): Inventor networks in renewable energies: The influence of the policy mix in Germany. Research Policy 45 (6), 1165 1184. 10.1016/j.respol.2016.03.005.

Conti, C., Mancusi, M. L., Sanna-Randaccio, F., Sestini, R., Verdolini, E. (2016): Transition Towards a Green Economy in Europe: Innovation and Knowledge Integration in the Renewable Energy Sector, Fondazione Eni Enrico Mattei, Nota Di Lavoro 71.2016, Milano http:/www.feem.it/userfiles/attach/2017515113174NDL2016-071.pdf 
Costantini, V., Crespi, F., Palma, A. (2017): Characterizing the policy mix and its impact on eco-innovation: A patent analysis of energy-efficient technologies. Research Policy 46 (4), 799-819. 10.1016/j.respol.2017.02.004.

Demirel, P., Kesidou, E. (2012): Stimulating different types of eco-innovation in the UK: Government policies and firm motivations. Ecological Economics 70 (8): 1546-1557.

Eckey, H.-F. (2008): Regionalökonomie. Gabler Verlag, Wiesbaden.

Eickelpasch A., Lejpras A., Stephan A. (2011): Locational and internal sources of firm competitive advantage: applying Porter's diamond model at the firm level. Journal of Strategic Management and Education 7(2): 129-154.

Eurostat (2015): Questionnaire of the Community Innovation Survey 2014, Luxembourg.

Foster, E., Contestabile, M., Blazquez, J., Manzano, B., Workman, M., Shah, N. (2017): The unstudied barriers to widespread renewable energy deployment: Fossil fuel price responses. Energy Policy 103: 258-264.

Frondel, M., Ritter, N., Schmidt, C. M., Vance, C. (2010): Economic impacts from the promotion of renewable energy technologies: the German experience. Energy Policy 38: 4048-4056.

Gawel, E., Lehmann, P., Korte, K., Strunz, S., Bovet, J., Köck, W., Massier, P., Löschel, A., Schober, D., Ohlhorst, D., Tews, K., Schreurs, M., Reeg, M., Wassermann, S. (2014): The future of the energy transition in Germany. Energy, Sustainability and Society 4 (15): $1-9$.

Groba, F., Breitschopf, B. (2013): Impact of Renewable Energy Policy and Use on Innovation. A Literature Review, DIW Discussion Paper 1318, Berlin.

Grupp, H. (1999): Umweltfreundliche Innovation durch Preissignale oder Regulation? - Eine empirische Untersuchung für Deutschland. Jahrbücher für Nationalökonomie und Statistik $219(5,6)$ : 611-631.

Horbach, J., Rammer, C., Rennings, K. (2012): Determinants of Eco-innovations by Type of Environmental Impact - The Role of Regulatory Push/Pull, Technology Push and Market Pull. Ecological Economics 78: 112-122.

Horbach, J. (2014): Do eco-innovations need specific regional characteristics? An econometric analysis for Germany. Review of Regional Research 34 (1): 23-38.

Horbach, J. (2015): The role of environmental policy for eco-innovation: Theoretical background and empirical results for different countries. In: Crespi, F., Quatraro, F. (eds.): 
The Economics of Knowledge, Innovation and Systemic Technology Policy, Routledge, London, New York: 348-360.

Johnstone, N., Haščič, I., Popp, D. (2010): Renewable Energy Policies and Technological Innovation: Evidence Based on Patent Counts. Environmental and Resource Economics 45: 133-155.

Krugman, P. (1991): Geography and Trade. MIT Press, Cambridge.

Nesta, L., Vona, F., Nicolli, F. (2014): Environmental policies, competition and innovation in renewable energy. Journal of Environmental Economics and Management 67 (3): 396411.

Noailly, J, Smeets, R. (2016): Financing energy innovation: The role of financing constraints for directed technical change from fossil-fuel to renewable innovation, EIB Working Papers 2016/06, Luxembourg, http://www.eib.org/attachments/efs/economics working paper 201606 en.pdf

Pohl, B., Mulder, P. (2013): Explaining the Diffusion of Renewable Energy Technology in Developing Countries. GIGA (German Institute of Global and Area Studies) Working Papers 217, Hamburg, http://edoc.vifapol.de/opus/volltexte/2013/4499/pdf/wp217_pohl_mulder.pdf

Porter, M. E. (2000): Locations, clusters and company strategy. In: Clark, G. L., Feldman, M. P., Gertler, M. S. (eds.) (2000): The Oxford Handbook of Economic Geography. Oxford University Press, Oxford.

Rammer, C., Gottschalk, S., Peneder, M., Wörter, M., Stucki, T., Arvanitis, S. (2017): Does energy policy hurt international competitiveness of firms? A comparative study for Germany, Switzerland and Austria. Energy Policy 109:154-180.

Schleich, J., Walz, R., Ragwitz, M. (2017): Effects of policies on patenting in wind-power technologies. Energy Policy 108: 684-695.

StataCorp (2015): The STATA manual 2015. Stata Press, Lakeway Drive.

Statistisches Bundesamt (2017): Regionaldatenbank Deutschland. Wiesbaden. www.regionalstatistik.de

Vona, F., Nicolli, F., Nesta, L. (2012): Determinants of Renewable Energy Innovation: Environmental Policies vs. Market Regulation. OFCE Documents de Travail 2012-05, Paris. 


\section{Appendix 1: Definition of variables and descriptive statistics}

\begin{tabular}{|c|c|c|c|}
\hline Name of variable & Description & Mean & SD \\
\hline Renewable & $\begin{array}{l}1 \text { Innovations leading to a substitution of fossil energy sources by } \\
\text { renewables, } 0 \text { Firms without such innovations }\end{array}$ & 0.11 & 0.31 \\
\hline \multicolumn{4}{|l|}{$\begin{array}{l}\text { Regional variables } \\
\text { (NUTS 3) }\end{array}$} \\
\hline Popdens & Population 2012 per $\mathrm{qm}^{2} / 1000$ & 1.07 & 1.26 \\
\hline Secshare & Share of a firm's sector in the NUTS 3 unit & 0.17 & 0.13 \\
\hline Sharegreen & Voting share of the green party in 2013 & 0.09 & 0.04 \\
\hline Solbiocapita & Solar-, biomass and gas energy plants in (kwp per capita)/1000 & 0.05 & 0.06 \\
\hline Watercapita & Water energy plants in (kwp per capita)/1000 & 0.002 & 0.004 \\
\hline Windcapita & Wind energy plants in (kwp per capita)/1000 & 0.04 & 0.09 \\
\hline \multicolumn{4}{|l|}{$\begin{array}{l}\text { Technological capa- } \\
\text { bilities }\end{array}$} \\
\hline Externrd & External $R \& D$ activities ( 1 yes, 0 no) & 0.11 & 0.31 \\
\hline Internrd & Internal $R \& D$ activities ( 1 yes, 0 no) & 0.35 & 0.48 \\
\hline Orgcoop & Newly organised relationships to other firms ( 1 yes, 0 no) & 0.13 & 0.33 \\
\hline Orgproc & New methods for organisation of business processes ( 1 yes, 0 no) & 0.22 & 0.41 \\
\hline Orgwork & New forms of labour organisation ( 1 yes, 0 no) & 0.21 & 0.41 \\
\hline Coopown & Cooperations with firms of the own firm group ( 1 yes, 0 no) & 0.04 & 0.20 \\
\hline Coopclient & Cooperations with clients ( 1 yes, 0 no) & 0.06 & 0.23 \\
\hline Coopsuppcomp & Cooperations with suppliers and competitors ( 1 yes, 0 no) & 0.06 & 0.24 \\
\hline Coopresearch & $\begin{array}{l}\text { Cooperations with consulters, universities, public and private } \\
\text { research }(1 \text { yes, } 0 \text { no) }\end{array}$ & 0.12 & 0.32 \\
\hline Highqual & Share of employees with university degree & 0.22 & 0.28 \\
\hline Determinants & 1 high or medium, 0 low or not relevant & & \\
\hline Regulation & Fulfillment of present laws and standards & 0.27 & 0.45 \\
\hline Taxes & Existing environmental taxes & 0.15 & 0.35 \\
\hline Futurelaw & Anticipation of future regulations & 0.20 & 0.40 \\
\hline Subsidies & Subsidies from German ministries ( 1 yes, 0 no) & 0.02 & 0.12 \\
\hline EcoSubsidies & Public support of eco-innovation & 0.11 & 0.31 \\
\hline Demand & Demand for eco-innovation & 0.14 & 0.35 \\
\hline Reputation & Improvement of the reputation of the firm & 0.22 & 0.42 \\
\hline Selfcommitment & Self-commitments or industry standards & 0.21 & 0.41 \\
\hline Energcost & Rising energy or material costs & 0.35 & 0.48 \\
\hline \multicolumn{4}{|l|}{ Appropriation } \\
\hline Patents & Patent applications ( 1 yes, 0 no) & 0.11 & 0.31 \\
\hline Designs & Use of utility models and registered designs ( 1 yes, 0 no) & 0.07 & 0.26 \\
\hline Trademarks & Application of trademarks ( 1 yes, 0 no) & 0.13 & 0.34 \\
\hline Copyrights & Enforcement of copyrights ( 1 yes, 0 no) & 0.05 & 0.22 \\
\hline \multicolumn{4}{|l|}{ Control variables } \\
\hline Agefirm & Age of the firm $(2014-$ year of foundation +0.5$) / 1000$ & 0.03 & 0.04 \\
\hline Competition & $\begin{array}{l}\text { High competition intensity by foreign firms ( } 1 \text { highly relevant, } 0 \\
\text { other) }\end{array}$ & 0.30 & 0.46 \\
\hline Number competitors & Number of competitors ( 1 more than 15,0 other) & 0.26 & 0.44 \\
\hline Family & Family dominated (at least $50 \%$ of firm shares) ( 1 yes, 0 no) & 0.52 & 0.50 \\
\hline International & Exporting in international markets ( 1 yes, 0 no) & 0.45 & 0.50 \\
\hline Profit & 1 Profit margin $>5 \%, 0$ other & 0.44 & 0.50 \\
\hline Size & Number of employees 2012 (in 1000) & 0.69 & 4.24 \\
\hline
\end{tabular}




\begin{tabular}{|l|l|l|l|}
\hline Sector dummies & (1 yes, 0 no) & & \\
Sec1 & Food products and beverages, tobacco & 0.04 & 0.20 \\
Sec2 & Textiles, clothing, leather products & 0.03 & 0.16 \\
Sec3 & Wood and paper products, printing & 0.02 & 0.16 \\
Sec4 & Chemical and pharmaceutical industry & 0.03 & 0.17 \\
Sec5 & Rubber and plastic products & 0.02 & 0.15 \\
Sec6 & Glass, ceramics and concrete products & 0.02 & 0.14 \\
Sec7 & Basic metals and fabricated metals & 0.07 & 0.25 \\
Sec8 & Electrical machinery, electronics, instruments & 0.05 & 0.22 \\
Sec9 & Machinery & 0.07 & 0.25 \\
Sec10 & Motor vehicles, other transport equipment & 0.02 & 0.16 \\
Sec11 & Medial products, furniture and other products & 0.05 & 0.23 \\
Sec12 & Energy and water supply, mining, mineral industry & 0.04 & 0.18 \\
Sec13 & Recycling, waste and waste water removal & 0.04 & 0.20 \\
Sec14 & Wholesale trade & 0.04 & 0.19 \\
Sec15 & Transport and logistics & 0.07 & 0.26 \\
Sec16 & Media services & 0.04 & 0.20 \\
Sec17 & Computer programming, data processing and telecommunication & 0.04 & 0.21 \\
Sec18 & Financial intermediation & 0.05 & 0.21 \\
Sec19 & Technical and R\&D services & 0.07 & 0.26 \\
Sec20 & Consulting and marketing & 0.06 & 0.24 \\
Sec21 & Business services, other & 0.11 & 032 \\
\hline
\end{tabular}

